\title{
Sc applications in aluminum alloys: overview of Russian research in the 20th century
}

\author{
Dmitry G. Eskin
}

BCAST, Brunel University London, Uxbridge UB8 3PH, United Kingdom

Dmitry.Eskin@brunel.ac.uk

Tel +44 1895265317

\begin{abstract}
Following the pioneering patent of Willey on Al-Sc alloys (1971), an extensive research program has started in the USSR in the 1970s, dedicated both to the fundamentals of interaction and mechanisms of Sc in $\mathrm{Al}$ and to the development of Sc-containing aluminum alloys. A number of very important phase diagrams of practically important systems have been experimentally studied and laid the foundation for the development of wrought and casting alloys with $\mathrm{Sc}$. The unique equilibrium $\mathrm{L1}_{2} \mathrm{Al}_{3} \mathrm{Sc}$ phase has been characterized and its role in grain refinement, precipitation hardening and preventing recrystallization has been identified and explained. Interaction of Sc with other transition elements, in particular $\mathrm{Zr}$, has been investigated. A number of alloys of Al-Mg, Al-Li-Mg, Al-Zn-Mg, Al-Cu systems with particular properties, e.g. high strength, weldablity, superplasticity, have been developed and commercialized in the 1980-1990s. This presentation gives an overview of those developments.
\end{abstract}

Keywords: Scandium; Precipitation; Recrystallization; Hardening; Aluminum Alloy

\section{Introduction}

The first patent on Sc-containing alloys is dated 1971 and was obtained by Willey of Alcoa [1]. This invention covered aluminum alloys containing up to $5 \%$ Sc (typically $0.2-0.6 \%$ ) and also claimed hardening heat treatment in the temperature range $100-425^{\circ} \mathrm{C}$. This triggered huge interest to the mechanisms of Sc in $\mathrm{Al}$ alloys and to the phase diagrams of practically important Al systems with Sc. Russian schools of phase diagrams in particular in Baikov Institute of Metallurgy and Lomonosov Moscow State University became involved in studying the phase equilibria in these systems. This laid the foundation for the informed development and commercialization of $\mathrm{Al}-\mathrm{Mg}, \mathrm{Al}-\mathrm{Li}$ and other aluminum alloys containing small additions of Sc as well as to the research in the phases formed at various stages of alloy processing, from casting to deformation; and eventually to the mechanisms of grain 
refinement, precipitation hardening and recrystallization control. These works were concentrated in the Baikov Institute of Metallurgy (IMET), All-Russia Institute of Light Alloys (VILS) and All-Russia Institute of Aviation Materials (VIAM).

Aluminum alloys containing scandium (frequently in combination with zirconium) use several mechanisms to control structure and properties. Primary particles of aluminides act as nucleants for the aluminum solid solution during solidification. Considerable amount of scandium is retained in the solid solution after solidification. This supersaturated solid solution decomposes at relatively high temperatures $\left(250\right.$ to $\left.350{ }^{\circ} \mathrm{C}\right)$ with the formation of coherent and semi-coherent particles that can either harden the alloy (this effect is used in $\mathrm{Al}-\mathrm{Mg}$ alloys) or retard recrystallization (this is used in heat treatable aluminum alloys).

\section{Phase diagram development}

The first version of the $\mathrm{Al}-\mathrm{Sc}$ phase diagram reported a peritectic reaction in the $\mathrm{Al}$ corner [2]. This was later proved to be wrong and the well-known eutectic reaction was established in Al-rich alloys, $\mathrm{L} \rightarrow(\mathrm{Al})+\mathrm{Al}_{3} \mathrm{Sc}$ at $655^{\circ} \mathrm{C}$ with the eutectic point at $0.5-0.6 \mathrm{wt} \% \mathrm{Sc}$ and the limit solubility of $0.4 \mathrm{wt} \% 0.38 \mathrm{wt} \%$ [3], which is very close to the later data of the eutectic temperature at $656-660{ }^{\circ} \mathrm{C}$, eutectic point at $0.52-0.58 \mathrm{wt} \% \mathrm{Sc}$ and limit solubility at $0.38 \mathrm{wt} \%[4,5]$. The solid solubility of $\mathrm{Sc}$ in $(\mathrm{Al})$ rapidly decreases with temperature. The $\mathrm{Al}_{3} \mathrm{Sc}$ phase is formed at $1320{ }^{\circ} \mathrm{C}$ during a peritectic reaction, has a cubic ordered structure of $L 1_{2}$ type with a $=0.4104 \mathrm{~nm}$ [5]. Interestingly enough, recently the peritectic nature of reaction between $(\mathrm{Al})$ and $\mathrm{Al}_{3} \mathrm{Zr}$ came into question with a eutectic reaction suggested instead $[6]$.

It was shown that on increasing the cooling rate, the solubility of Sc in Al significantly increases while the eutectic temperature decreases as shown in Fig. $1[7,8]$. This created a base for the development of Sc-containing alloys that use supersaturation of the aluminum solid solution with scandium upon cooling during solidification.

The $\mathrm{Al}_{3} \mathrm{Sc}$ phase has been studied in detail, both the crystal structure [9] and mechanical properties [10].

Zirconium is an addition that is frequently used together with $\mathrm{Sc}$ to reduce the required amount of the latter and to increase the stability of the dispersion-hardened structure. 


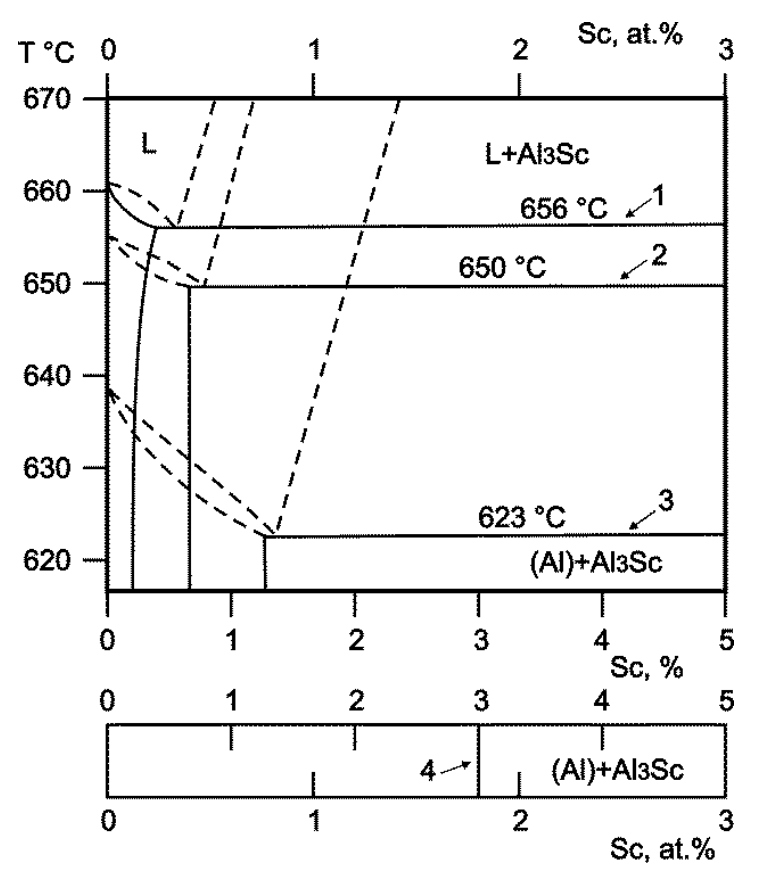

Figure 1. Metastable phase diagrams of the Al-Sc system as $5 \mathrm{~K} / \mathrm{s}(1) ; 10^{2} \mathrm{~K} / \mathrm{s}(2) ; 10^{3} \mathrm{~K} / \mathrm{s}$ (3) and $10^{5} \mathrm{~K} / \mathrm{s}(4)$. After [11].

The Al-Sc-Zr phase diagram is considered as a combination of eutectic and peritectic transformations on the respective sides of the concentration triangle. In the aluminum corner of this system only binary $\mathrm{Al}_{3} \mathrm{Sc}$ and $\mathrm{Al}_{3} \mathrm{Zr}$ phases are in the equilibrium with (Al) (Fig. 2). The $\mathrm{Al}_{3} \mathrm{Sc}$ phase can dissolve $\mathrm{Zr}$ up to the composition $\mathrm{Al}_{3} \mathrm{Sc}_{0.6} \mathrm{Zr}_{0.4}(35 \mathrm{wt} \% \mathrm{Zr})[12,13,14]$. The $\mathrm{Al}_{3} \mathrm{Zr}$ phase melts congruently at $1577^{\circ} \mathrm{C}$, has a tetragonal structure of $\mathrm{DO}_{23}$ type with a $=0.4006-0.4014 \mathrm{~nm}$ and $\mathrm{c}=1.727-1.732 \mathrm{~nm}$, and dissolves Sc up to the composition $\mathrm{Al}_{3} \mathrm{Zr}_{0.8} \mathrm{Sc}_{0.2}(5 \mathrm{wt} \% \mathrm{Sc})$. These phases participate in the invariant reaction $\mathrm{L}+\mathrm{Al}_{3} \mathrm{Zr} \rightarrow(\mathrm{Al})$ $+\mathrm{Al}_{3} \mathrm{Sc}$ at $659{ }^{\circ} \mathrm{C}$. Mutual equilibrium solubility of $\mathrm{Zr}$ and $\mathrm{Sc}$ in solid (Al) is $0.06 \% \mathrm{Zr}$, $0.03 \% \mathrm{Sc}$ at $550{ }^{\circ} \mathrm{C}$ and $0.09 \% \mathrm{Zr}, 0.06 \% \mathrm{Sc}$ at $600{ }^{\circ} \mathrm{C}$ [11].

The typical concentrations of scandium and zirconium in commercial aluminum alloys are lower than $0.3 \% \mathrm{Sc}$ and $0.15 \% \mathrm{Zr}$ or $<0.45 \%$ in total. Depending on the $\mathrm{Zr}$ :Sc ratio, either $\mathrm{Al}_{3} \mathrm{Sc}(\mathrm{Zr}: \mathrm{Sc}<1)$ or $\mathrm{Al}_{3} \mathrm{Zr}(\mathrm{Zr}: \mathrm{Sc}>1)$ solidifies as primary phase. Some authors suggest the formation of a ternary $\mathrm{Al}_{3}(\mathrm{ScZr})$ phase with the crystal structure similar to that of stable $\mathrm{Al}_{3} \mathrm{Sc}$ and metastable $\mathrm{Al}_{3} \mathrm{Zr}$. However, there is no evidence in favor of the formation of a new phase in the $\mathrm{Al}-\mathrm{Sc}-\mathrm{Zr}$ system. Metallographic examination of primary particles in $\mathrm{Al}-\mathrm{Sc}-\mathrm{Zr}$ alloys show that $\mathrm{Al}_{3} \mathrm{Sc}$ phase forms a rim on primary $\mathrm{Al}_{3} \mathrm{Zr}$ particles [11]. This surface layer possesses very good refining ability of $\mathrm{Al}_{3} \mathrm{Sc}$ and "activates" $\mathrm{Al}_{3} \mathrm{Zr}$, allowing strong grain refinement at relatively low Sc concentrations. 

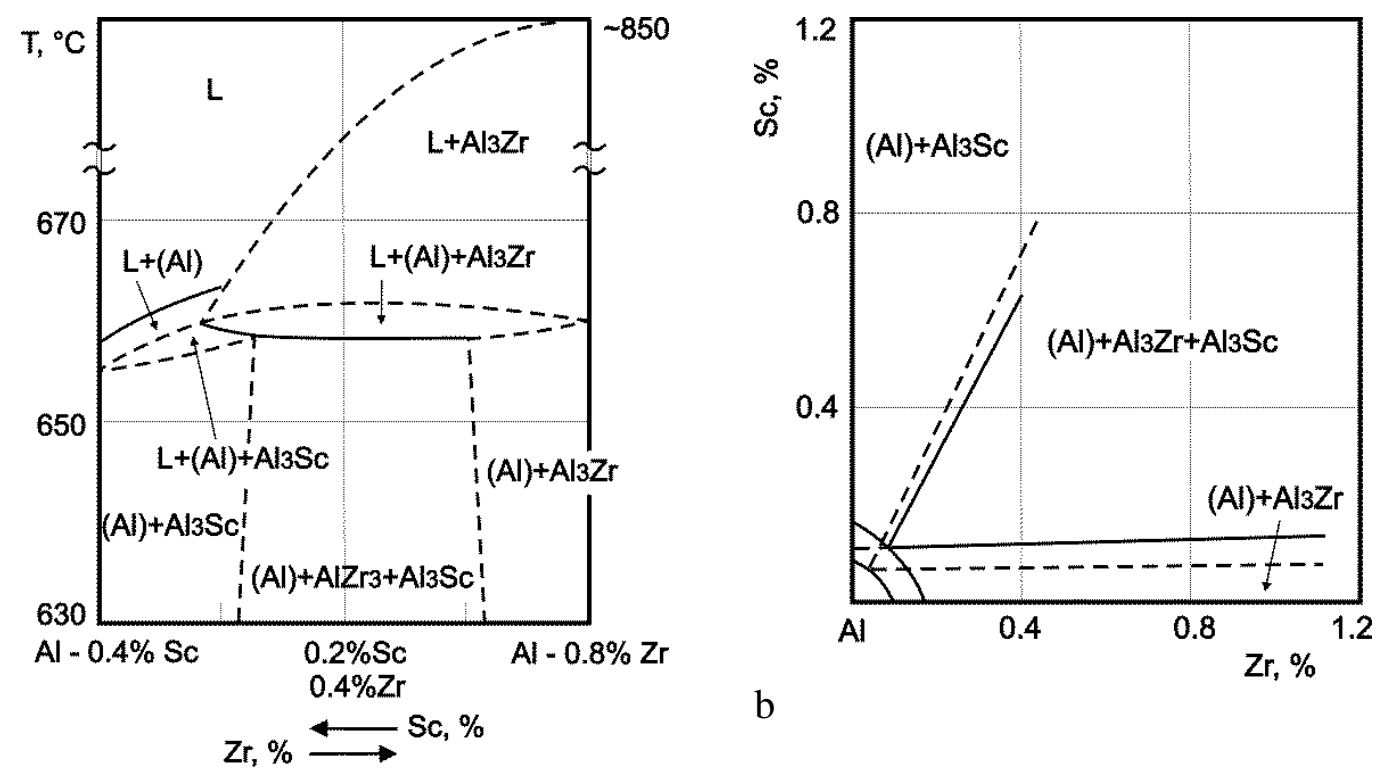

a

Figure 2. Section of the $\mathrm{Al}-\mathrm{Sc}-\mathrm{Zr}$ phase diagram: (a) polythermal section from $\mathrm{Al}-0.4 \% \mathrm{Sc}$ to $\mathrm{Al}-0.8 \% \mathrm{Zr}$ and (b) isothermal sections at $550{ }^{\circ} \mathrm{C}$ (dashed lines) and $600{ }^{\circ} \mathrm{C}$ (solid lines). After [11].

Another practically important phase diagram is of the $\mathrm{Al}-\mathrm{Mg}-\mathrm{Sc}$ system that is a foundation for a new class of precipitation hardened $\mathrm{Al}-\mathrm{Mg}$ alloys. The invariant eutectic reaction $\mathrm{L} \rightarrow$ (Al) $+\mathrm{Al}_{3} \mathrm{Sc}+\mathrm{Al}_{8} \mathrm{Mg}_{5}$ occurs in the aluminum corner of the system at $447 \pm 3{ }^{\circ} \mathrm{C}$ and $0.1-$ $0.5 \% \mathrm{Sc}$ [15]. Figure 3a gives a polythermal section of the Al-rich portion of the $\mathrm{Al}-\mathrm{Mg}-\mathrm{Sc}$ phase diagram. Under real casting conditions, the solidification continues down to 447-450 ${ }^{\circ} \mathrm{C}$ when the ternary $(\mathrm{Al})+\mathrm{Al}_{3} \mathrm{Sc}+\mathrm{Al}_{8} \mathrm{Mg}_{5}$ eutectics is formed.

Commercial alloys of 1570-type (5-6\% Mg) usually contain less than $0.3 \%$ Sc (typical concentrations of $\mathrm{Sc}$ and $\mathrm{Zr}$ are less than $0.15 \%$ each). In this compositional range, the ternary $\mathrm{Al}-\mathrm{Mg}-\mathrm{Sc}$ alloy is on the border between primary solidification of either $(\mathrm{Al})$ or $\mathrm{Al}_{3} \mathrm{Sc}$. However, if we take into account the joint presence of $\mathrm{Sc}$ and $\mathrm{Zr}$ in commercial alloys and the mechanism of their formation (Fig. 2), it becomes clear that the typical concentration of $\mathrm{Sc}$ and $\mathrm{Zr}$ is sufficient for very good grain refining of $\mathrm{Al}-\mathrm{Mg}$ alloy upon casting. 




a

Figure 3. (a) A polythermal section from $\mathrm{Al}-17 \% \mathrm{Mg}$ to $\mathrm{Al}-1 \% \mathrm{Sc}$ of the $\mathrm{Al}-\mathrm{Mg}-\mathrm{Sc}$ phase diagram and (b) solid solubility of $\mathrm{Mg}$ and $\mathrm{Sc}$ in (Al). After [11].

In addition to grain refinement, the main purpose of introduction of $\mathrm{Sc}$ to $\mathrm{Al}-\mathrm{Mg}$ alloys is to assure the precipitation of coherent $\mathrm{Al}_{3} \mathrm{Sc}$ particles from the supersaturated solid solution. The precipitation hardening and structural hardening (due to the retarded recrystallization) significantly add to the solid-solution hardening effect that is the typical mechanism of strengthening of $\mathrm{Al}-\mathrm{Mg}$ alloys. Therefore, the solubility of $\mathrm{Mg}$ and $\mathrm{Sc}$ are of great importance in these alloys. It has been shown that the solubility of magnesium in solid aluminum considerably decreases in the presence of scandium. The limit solubility of $\mathrm{Mg}$ and $\mathrm{Sc}$ in solid aluminum at the temperature of the ternary eutectics is $10.5 \% \mathrm{Mg}$ and $0.007 \% \mathrm{Sc}$ as compared to $13.5-14 \% \mathrm{Mg}$ in the binary system [11]. The solubility of $\mathrm{Mg}$ and $\mathrm{Sc}$ decreases with temperature as shown in Fig. 3b. These data are useful for the correct choice of annealing temperatures for homogenization or precipitation.

Another implication of adding $\mathrm{Mg}$ to Al-Sc alloys is the fact that magnesium increases the lattice parameter of the aluminum solid solution and, hence decreases the dimensional misfit between $\mathrm{Al}_{3} \mathrm{Sc}$ and the matrix (from 0.012 in a binary $\mathrm{Al}-\mathrm{Sc}$ alloy to 0.00054 in a ternary $\mathrm{Al}-$ $6.5 \% \mathrm{Mg}-\mathrm{Sc}$ alloy [16]). As a result, the coherency of $\mathrm{Al}_{3} \mathrm{Sc}$ is retained at higher temperatures and on longer exposures, providing for a higher thermal stability of $\mathrm{Al}-\mathrm{Mg}-\mathrm{Sc}$ alloys.

Other phase diagrams of commercially important systems such as $\mathrm{Al}-\mathrm{Cu}-\mathrm{Sc}, \mathrm{Al}-\mathrm{Si}-\mathrm{Sc}, \mathrm{Al}-$ $\mathrm{Li}-\mathrm{Sc}, \mathrm{Al}-\mathrm{Li}-\mathrm{Mg}-\mathrm{Sc}$, and $\mathrm{Al}-\mathrm{Cu}-\mathrm{Mg}-\mathrm{Zn}-\mathrm{Sc}-\mathrm{Zr}$ have been thoroughly investigated by Russian research groups as well and the reviews can be found elsewhere [11, 17]. 


\section{Precipitation in Sc-containing aluminum alloys}

The aluminum solid solution tends to supersturate with transition metals upon cooling after solidification. Al-Sc alloys are vivid representatives of this behavior (see Fig. 1). Of course the supersaturated solid solution can be obtained also by quenching after high-temperature anneal. The decomposition of supersaturated solid solutions with $\mathrm{Sc}$ is the foundational mechanism for precipitation hardening and recrystallization retarding in aluminum alloys as was extensively studied by Drits et al. [16, 18, 19].

It was established that the decomposition occurs with precipitation of fine, spherical, coherent particles of the equilibrium $\mathrm{Al}_{3} \mathrm{Sc}$ phase. This is the unique characteristic of $\mathrm{Al}-\mathrm{Sc}$ alloys as in most of precipitation hardened alloys, intermediate metastable phases precipitate and cause hardening. It was also demonstrated that the effective temperature range of hardening in between 250 and $350{ }^{\circ} \mathrm{C}$ with the maximum strength achieved after several hours of annealing. The equilibrium $\mathrm{Al}_{3} \mathrm{Sc}$ phase has a cubic structure with the lattice parameter very close to that of aluminum, which enables homogeneous nucleation of particles just a few nm in diameter as illustrated in Fig. 4 [11]. The selected area diffraction pattern shows only superstructure reflections, while the particles give a distinct Ashby-Brown deformation contrast from the surrounding elastic field. The coherent precipitates are quite stable at temperatures below $350{ }^{\circ} \mathrm{C}$ for over $100 \mathrm{~h}$. On increasing the annealing temperature above $400{ }^{\circ} \mathrm{C}$, the particles loose coherency and become semi-coherent after $50 \mathrm{~h}$ [11]. The main mechanisms of hardening are shearing of small coherent precipitates at the maximum strength stage (e.g. $250{ }^{\circ} \mathrm{C}, 50 \mathrm{~h}$ ) followed by Orowan hardening by dislocation loop formation after the coherency loss. The strengthening in the Al-Sc system is the highest among aluminum alloys, reaching 1000 in terms of the increase in the yield strength normalized to the total amount of alloying elements as compared to $191 \mathrm{in} \mathrm{Al}-\mathrm{Li}-\mathrm{Mg}$ alloys, 77 in $\mathrm{Al}-\mathrm{Cu}-\mathrm{Mg}$ alloys, and only 48 in $\mathrm{Al}-\mathrm{Zn}-\mathrm{Mg}-\mathrm{Cu}$ alloys [11].

The Al-Sc system is often used as a model system for studying nucleation, growth and hardening during decomposition of a supersaturated solid solution; owing to the unique features such as precipitation of the equilibrium phase, its homogenous nucleation, spherical shape of the particles, and their uniform distribution in the matrix.

One of the most common group of alloys, i.e. Al-Mg AA5XXX series, acquires the ability to harden via precipitation thanks to alloying with Sc. Conventionally, these alloys are subjected to solution hardening due to the high solubility of $\mathrm{Mg}$ in $\mathrm{Al}$. The addition of Sc and its 
supoersturation in the $\mathrm{Al}$ solid solution during solidification makes it possible to combine the solution hardening of $\mathrm{Mg}$ with precipitation hardening by $\mathrm{Al}_{3} \mathrm{Sc}$ at $250-300{ }^{\circ} \mathrm{C}$. This combination is not possible or is not beneficial in other $\mathrm{Al}$ alloys that are usually aged at 130-195 ${ }^{\circ} \mathrm{C}$ for precipitation of hardening metastable phases. In these alloys, the strengthening effect of conventional precipitation will be lost upon higher-temperature precipitation of $\mathrm{Al}_{3} \mathrm{Sc}$. Figure 5a illustrates the benefits of alloying $\mathrm{Al}-\mathrm{Mg}$ alloys with Sc.

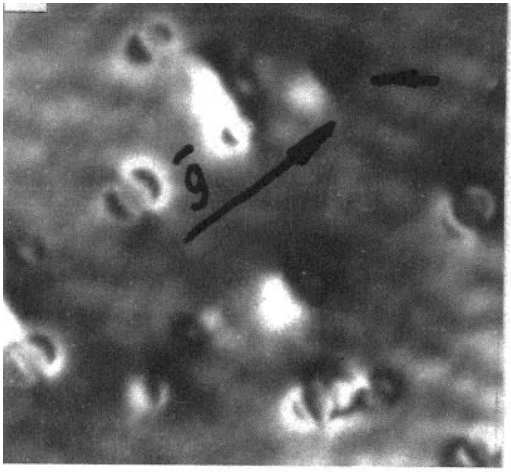

a



b

Figure 4. Precipitation of coherent $\mathrm{Al}_{3} \mathrm{Sc}$ particles in an $\mathrm{Al}-0.6 \% \mathrm{Sc}$ alloy at $350{ }^{\circ} \mathrm{C}, 100 \mathrm{~h}$ : (a) microstructure showing particles $13 \mathrm{~nm}$ in diameter and (b) (100) electron diffraction pattern showing superstructure reflections. After [11].

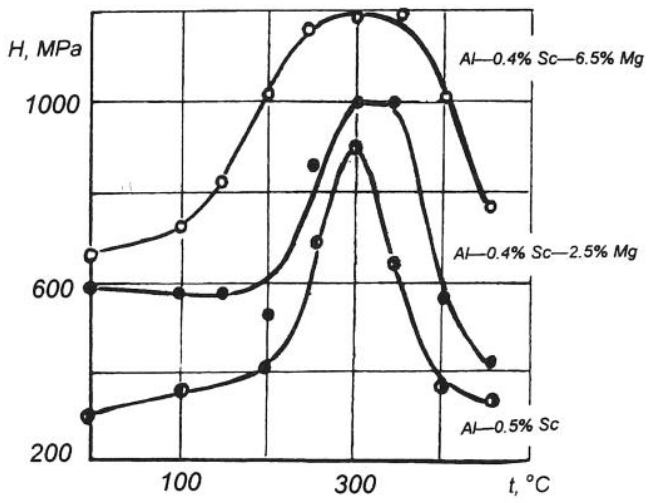

a

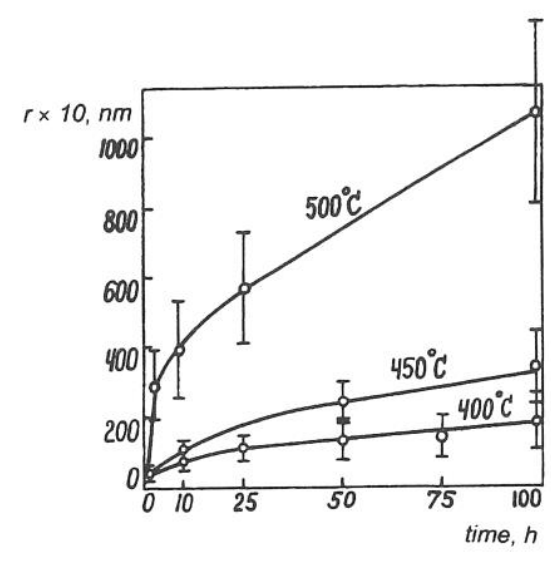

b

Figure 5. Effects of precipitation in Al-Mg-Sc alloys: (a) hardening in binay Al-Sc and ternary $\mathrm{Al}-\mathrm{Mg}-\mathrm{Sc}$ alloys and (b) evolution of $\mathrm{Al}_{3} \mathrm{Sc}$ radius during aging of an $\mathrm{Al}-6.5 \% \mathrm{Mg}-$ $0.4 \%$ Sc alloys at different temperatures. After [11].

The studies of precipitate evolution showed that $\mathrm{Al}_{3} \mathrm{Sc}$ precipitates are rather stable in $\mathrm{Al}-\mathrm{Mg}$ alloys and preserve their coherency up to radii of $65 \mathrm{~nm}$ (anneals at $400-450{ }^{\circ} \mathrm{C}$ for $10 \mathrm{~h}$ ), 
which is 2-3 times larger than in binary Al-Sc alloys [20]. This is related to the reduced misfit between the precipitates and the $\mathrm{Al}-\mathrm{Mg}$ matrix.

It was already mentioned that $\mathrm{Sc}$ and $\mathrm{Zr}$ are commonly used jointly in $\mathrm{Al}$ alloys. This has an advantage of reducing the required amount of expensive Sc but also has another advantage of increasing the stability of the hardening effect. Figure 6 shows that ternary Al-Sc-Zr alloys may have a lower absolute hardening effect but it is more stable at longer holding times and at higher temperatures. This is a result of joint precipitation of two $\mathrm{L1}_{2}$ phases, i.e. equilibrium $\mathrm{Al}_{3} \mathrm{Sc}$ and metastable $\mathrm{Al}_{3} \mathrm{Zr}$. It is demonstrated that the former precipitates are larger while the latter much finer as shown in Fig. 7. The concurrent precipitation of two similar and coherent phases slows down the softening of the alloy and preserves high hardening effect to higher temperatures and exposures. It should be noted that the precipitation of $\mathrm{Al}_{3} \mathrm{Sc}$ phase starts at a lower temperature than $\mathrm{Al}_{3} \mathrm{Zr}$, therefore the positive synergetic effect is observed at aging at $350-400{ }^{\circ} \mathrm{C}$ [21].

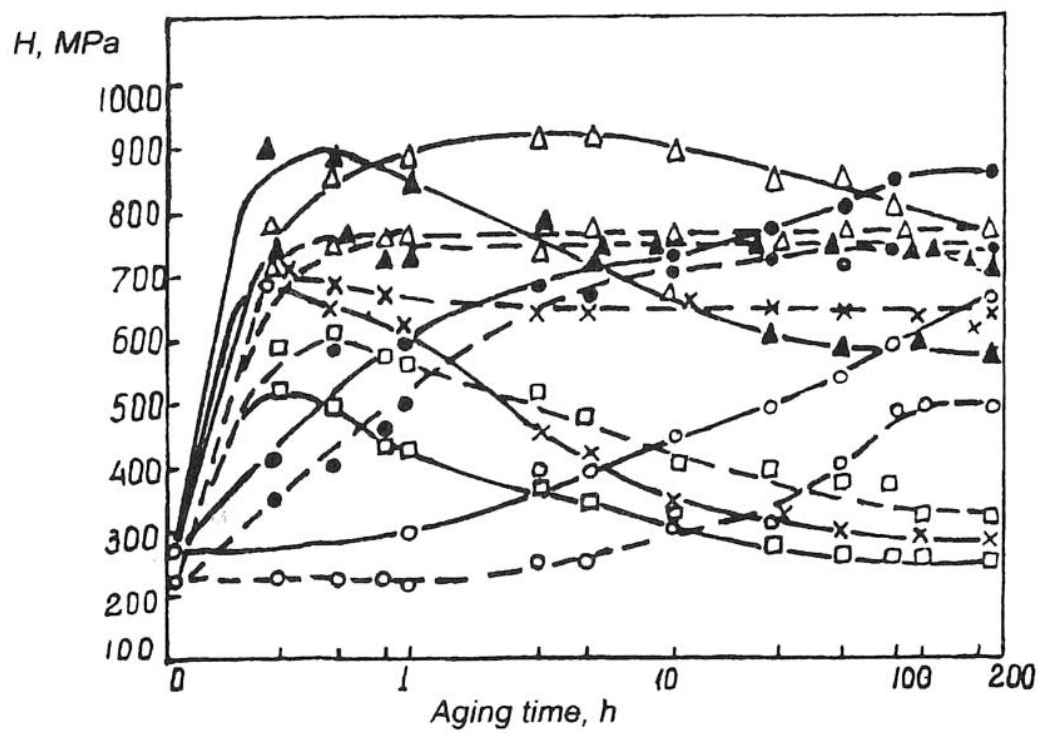

Figure 6. Aging curves for Al-0.3\% Sc (solid lines) and $\mathrm{Al}-0.3 \% \mathrm{Sc}-0.17 \% \mathrm{Zr}$ (dashed lines) at $200{ }^{\circ} \mathrm{C}(\circ) ; 300{ }^{\circ} \mathrm{C}(\bullet) ; 300{ }^{\circ} \mathrm{C}(\Delta) ; 350{ }^{\circ} \mathrm{C}(\Delta) ; 400{ }^{\circ}(\times)$; and $450{ }^{\circ} \mathrm{C}(\square)$. After [11]. 


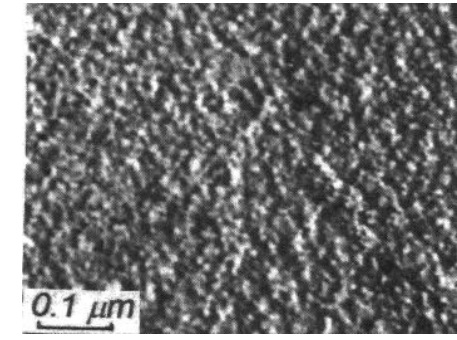

a
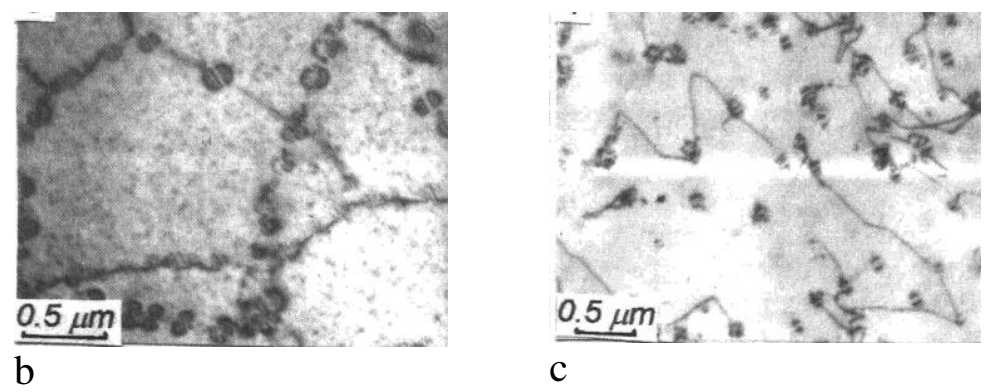

Figure 7. Precipitation in an Al-0.3\% Sc-0.17\% Zr alloy: $350{ }^{\circ} \mathrm{C}, 200 \mathrm{~h}$; (b) $400{ }^{\circ} \mathrm{C}, 200 \mathrm{~h}$; and (c) $450{ }^{\circ} \mathrm{C}, 10 \mathrm{~h}$. Larger particles in (b) are the equilibrium $\mathrm{Al}_{3} \mathrm{Sc}$ phase while smaller particles in (c) are the metastable $\mathrm{Al}_{3} \mathrm{Zr}$ phase. After [11].

There are some peculiarities in precipitation hardening in $\mathrm{Al}-\mathrm{Si}$ and $\mathrm{Al}-\mathrm{Li}$ alloys alloyed with Sc. It was shown that not $\mathrm{Al}_{3} \mathrm{Sc}$ phase but rather a metastable AlSiSc phase with spherical or ellipsoid-shaped particles precipitate in $\mathrm{Al}-\mathrm{Si}-\mathrm{Sc}$ alloys and effectively harden these alloys at $200-250{ }^{\circ} \mathrm{C}$ [22]. In $\mathrm{Al}-\mathrm{Li}$ alloys two $\mathrm{Ll}_{2}$ phases, i.e. $\mathrm{Al}_{3} \mathrm{Li}$ and $\mathrm{Al}_{3} \mathrm{Sc}$, precipitate. It is possible to perform two stage aging, with the first stage at $400{ }^{\circ} \mathrm{C}$ to form $\mathrm{Al}_{3} \mathrm{Sc}$ followed by a lower temperature stage at $200{ }^{\circ} \mathrm{C}$ to form $\mathrm{Al}_{3} \mathrm{Li}$ [23]. Composite particles with the $\mathrm{Al}_{3} \mathrm{Sc}$ core and the $\mathrm{Al}_{3} \mathrm{Li}$ envelope are typically observed in these alloys, driven by the reduction of interfacial and elastic energies.

\section{Recrystallization control}

Transition metals are common additions to aluminum alloys to control recrystallization via pinning of dislocations and grain boundaries by dispersoids precipitates upon homogenization of hot deformation. As a result the temperature of recrystallization onset and completion is increased. $\mathrm{Ti}$ and $\mathrm{Zr}$ increase the latter by 180 and $240{ }^{\circ} \mathrm{C}$, respectively [11]. The precipitates of $\mathrm{Al}_{3} \mathrm{Sc}$ retain their coherency to high temperatures and also grow rather slowly, so it is prudent to suggest that their effect on recrystallization development may be pronounced. The recrystallization of Al-Sc alloys has been studied for different starting conditions before cold rolling (annealed and forged; quenched in water, aged, or hot extruded) and for different Sc concentrations $[11,18]$. It has been shown that even small additions of Sc $(0.1-0.15 \%)$ sharply increase the recrystallization temperature. The temperature of recrystallization onset is increased to $350-375^{\circ} \mathrm{C}$ at $0.15-0.3 \%$ Sc and the temperature of recrystallization completion can be as high as $640^{\circ} \mathrm{C}$ in a hot extruded $\mathrm{Al}-$ $0.4 \%$ Sc alloy [11]. Figure 8 illustrated these effects. 

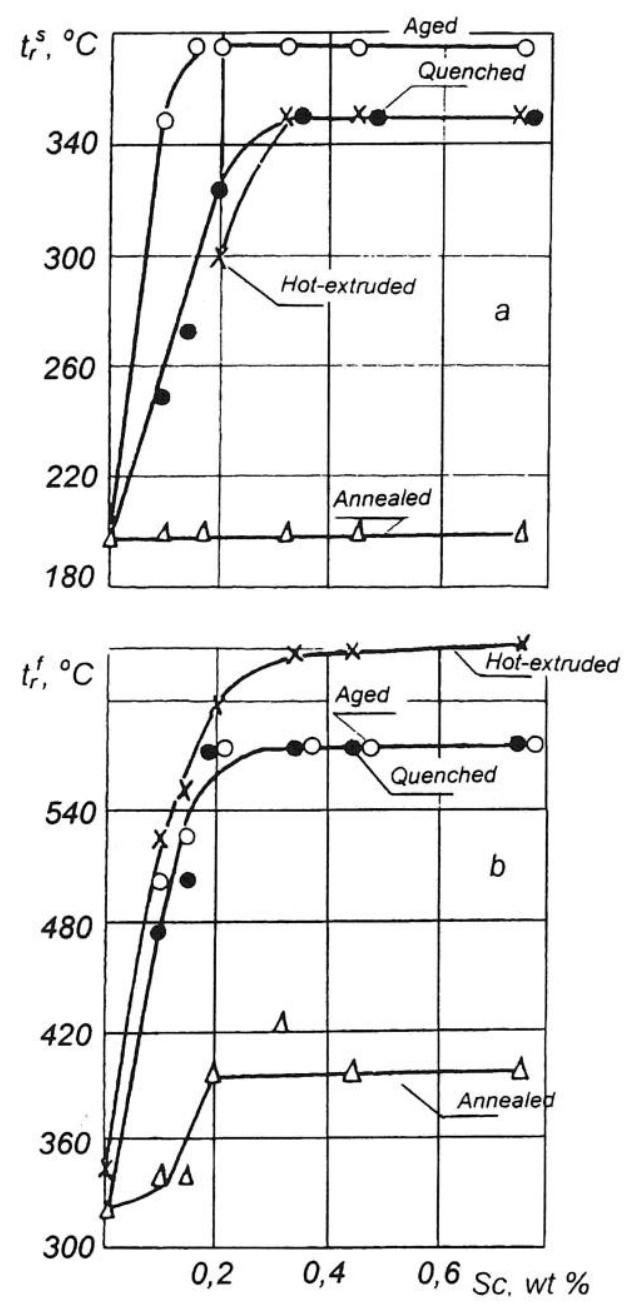

Figure 8. Effect of Sc additions on the recrystallization temperature of aluminum: (a) recrystallization onset and (b) recrystallization completetion. After [18].

The size and distribution of $\mathrm{Al}_{3} \mathrm{Sc}$ particles play the crucial role in the recrystallization control. Precipitates finer than $10 \mathrm{~nm}$ with the spacing smaller than $300 \mathrm{~nm}$ increase the onset of recrystallization by $125-175^{\circ} \mathrm{C}$ and shift the completion of recrystallization by $125-250$ ${ }^{\circ} \mathrm{C}$ [24]. On reaching the final recrystallization temperature the precipitates grow to $130-190$ $\mathrm{nm}$ with a spacing of $1.3-2.5 \mu \mathrm{m}[11]$.

The hindering of recrystallization is even more pronounced in $\mathrm{Al}-\mathrm{Mg}-\mathrm{Sc}$ alloys where, as it has been already mentioned, the stability of the precipitates is greater than in binary alloys. The maximum recrystallization onset temperature is achieved at Sc concentrations above $0.2 \%$ with no complete recrystallization possible at these concentrations as shown in Fig. 9. Particles with a diameter of $15-16 \mathrm{~nm}$ and spacing lesser than $170 \mathrm{~nm}$ are most efficient. A subgrain structure is typical with the cell size of 2-4 $\mu \mathrm{m}$ [25].

Additional alloying with $\mathrm{Zr}$ further increases the temperature stability of dispersoids and 
subgrain (polygonized) structure of deformed alloys [26]. This is illustrated in Fig. 10.

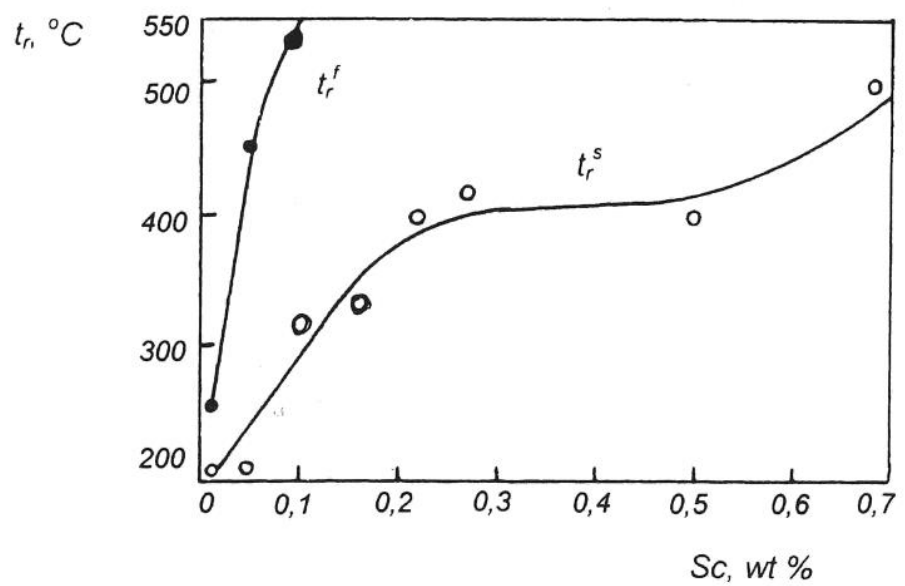

Figure 9. Effect of Sc concentration of the recrystallization temperatures in an Al-6.5\% Mg alloy. After [11].

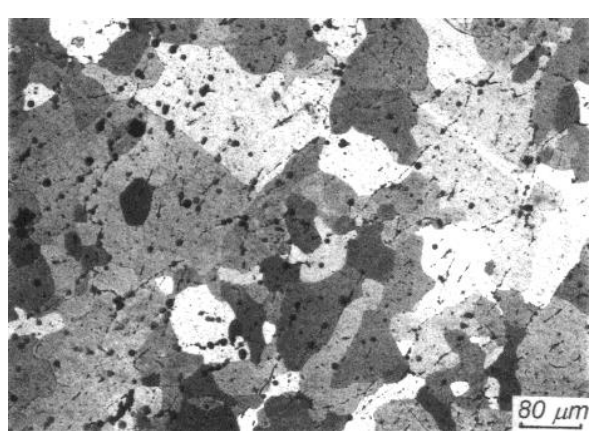

a

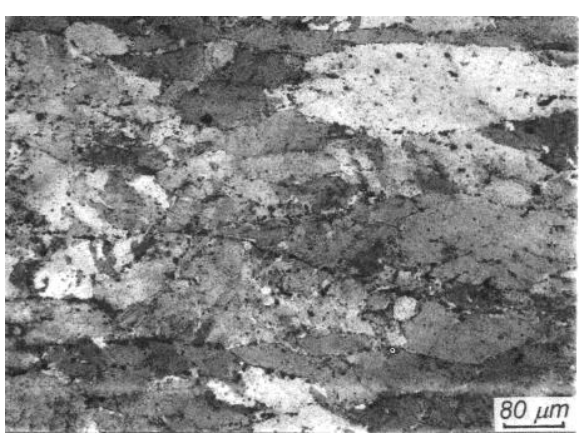

b

Figure 10. Grain structure of am AA6XXX alloy after homogenization at $480{ }^{\circ} \mathrm{C}$, hot rolling at $400{ }^{\circ} \mathrm{C}$ and quenched from $500{ }^{\circ} \mathrm{C}$ : (a) an alloy with Sc and $\mathrm{Zr}$ and (b) an alloy with Sc and Zr. After [27].

\section{Grain refinement upon solidification}

Primary $\mathrm{Al}_{3} \mathrm{Sc}$ particles are almost ideal substrates for $\mathrm{Al}$ as their crystal structure is very close to that of solid Al. The great grain refining ability of $\mathrm{Sc}$ in $\mathrm{Al}$ was first reported in the 1960s [28] and was later justified and confirmed on many occasions. In binary alloys, the grain refining is observed at hypereutectic compositions, i.e. above $0.5 \%$ Sc (Fig. 11). In ternary $\mathrm{Al}-\mathrm{Sc}-\mathrm{Zr}$ alloys, the grain refining effect is observed at lower concentrations of Sc. One of the possible explanations is that $\mathrm{Al}_{3} \mathrm{Sc}$ forms an envelope onto the primary $\mathrm{Al}_{3} \mathrm{Zr}$ particles, which requires much less Sc. Mutual additions of Sc and $\mathrm{Zr}(0.15 \%$ each) can even 
deliver a nondendritic structure in $\mathrm{Al}-\mathrm{Li}-\mathrm{Mg}, \mathrm{Al}-\mathrm{Mg}$ and $\mathrm{Al}-\mathrm{Zn}-\mathrm{Mg}$ alloys with the grain size as small as $20 \mu \mathrm{m}[29,30]$. This grain refining is particularly important upon welding as it helps avoiding hot cracking and reducing residual stresses, making the welding joint much stronger.

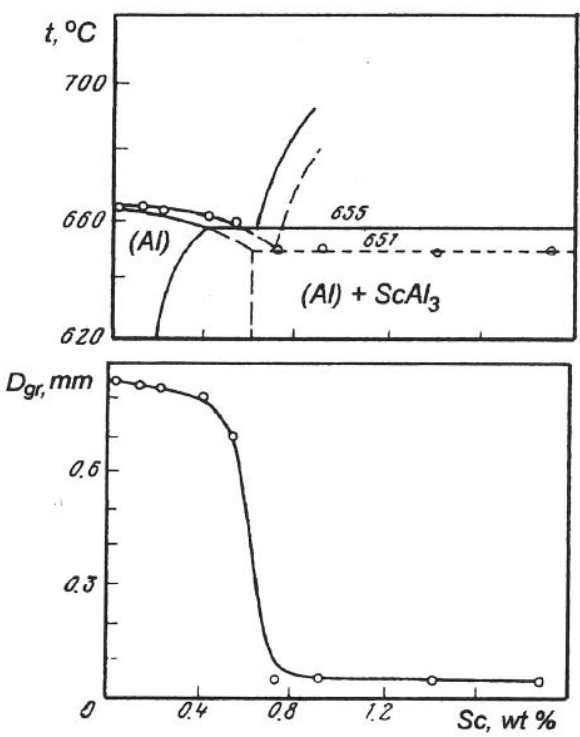

a



b

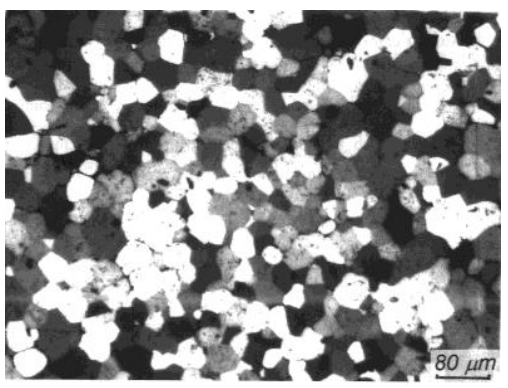

c

Figure 11. Grain refining upon solidification of Al-Sc alloys: (a) correlation of the grain refining with the composition; (b) an $\mathrm{Al}-\mathrm{Mg}$ alloy and (c) an $\mathrm{Al}-\mathrm{Mg}-\mathrm{Sc}-\mathrm{Zr}$ alloy.

\section{Commercial alloys with Sc}

In the USSR the fundamental research in the mechanisms of Sc in aluminum alloys resulted in the development and then commercialization of a number of wrought alloys. Addition of Sc to Al-Mg alloys allowed engineers to improve their weldability and significantly increase the strength (yield strength increment is $120 \mathrm{MPa}$ ), fracture toughness and thermal stability of properties (up to $250{ }^{\circ} \mathrm{C}$ and down to $-196{ }^{\circ} \mathrm{C}$ ) due to the precipitation of $\mathrm{Al}_{3} \mathrm{Sc}$. These alloys are typically homogenized at $400{ }^{\circ} \mathrm{C}$, and extruded or rolled at $250-300{ }^{\circ} \mathrm{C}$. A combination of refined as-cast grain structure, polygonized deformation structure and precipitation hardening results in a very advantageous combination of properties [11, 31]. Commercial alloys containing 6\% $\mathrm{Mg}(1570: 6 \% \mathrm{Mg}, 0.2 \% \mathrm{Sc}, 0.1 \%$ $\mathrm{Zr})$, and smaller amounts of $\mathrm{Mg}(1545,1535,1523,1515)$ have been developed and used in welded aerospace (e.g. fuel tanks, space platforms, heat exchangers, structural components) and marine (structural components) applications [31]. 
In heat-treatable aluminum alloys the effects of precipitation hardening with $\mathrm{Al}_{3} \mathrm{Sc}$ are hard to combine with the major processes of conventional ageing due to the large difference in required annealing temperatures, i.e. $250-300{ }^{\circ} \mathrm{C}$ vs $150-190{ }^{\circ} \mathrm{C}$. In these alloys alloying with Sc aims at the fine grain structure during solidification and welding as well on the restricting recrystallization.

An Al-Zn-Mg-Sc (1970) alloy was developed to substitute for AA2324 in aerospace applications, having advantages in corrosion resistance and weldability. Less alloyed 1935 and 1975 alloys can be used as extrusions in automotive and railway applications, to substitute AA6063-type alloys, being much stronger, tougher and weldable [31]. Important group of Sc-containing alloys is based on the $\mathrm{Al}-\mathrm{Li}-\mathrm{Mg}$ system. These alloys are intended for fuel tanks, aircraft structural parts and are used in some of MiG fighter jets and Beriev hydroplanes [32]. The grades include $1421(0.16-0.21 \%$ Sc) and $1430(0.01-0.1 \%$ Sc). Also Sc was added to some of Al-Cu-Li alloys $(1460,1461,1430,1469)$ in order to improve their strength, corrosion resistance and weldability. These alloys substitute for $\mathrm{Al}-$ $\mathrm{Cu}-\mathrm{Mg}$ alloys with $10-15 \%$ weight reduction.

Table 1 gives some examples of tensile properties for Sc-bearing aluminum alloys.

Table 1. Typical mechanical properties of Sc-containing commercial alloys [11, 31, 33

\begin{tabular}{|l|l|l|l|l|}
\hline $\begin{array}{l}\text { Alloy } \\
\text { grade/system }\end{array}$ & Product & YTS, MPa & El, \% \\
\hline $\begin{array}{l}1570(\mathrm{Al}-\mathrm{Mg}) \\
\begin{array}{l}\mathrm{Mg}(\mathrm{Al}-\mathrm{Zn}- \\
\mathrm{Mg})\end{array}\end{array}$ & Sheet (annealed) & 430 & 310 & 18 \\
\hline $\begin{array}{l}\text { Sheet (annealed) } \\
\mathrm{Mg})\end{array}$ & 510 & 450 & 13 \\
\hline $\begin{array}{l}1975(\mathrm{Al}-\mathrm{Zn}- \\
\mathrm{Mg})\end{array}$ & Sheet (annealed) & 440 & 350 & 18 \\
\hline $\begin{array}{l}1421(\mathrm{Al}-\mathrm{Li}- \\
\mathrm{Mg})\end{array}$ & Extrusion T1 & 510 & 460 & 14 \\
\hline $\begin{array}{l}1445(\mathrm{Al}-\mathrm{Mg}- \\
\mathrm{Li}-\mathrm{Cu})\end{array}$ & Extrusion T7 & 470 & 340 & 6 \\
\hline
\end{tabular}




\section{Concluding remark}

This overview shows a solid foundation laid by Russian scientists for the development and application of Sc-containing aluminum alloys. Main phase diagrams, specifics of precipitation, mechanisms of grain refining, hardening and recrystallization control have been developed in the 1970-1990s and have not lost value in the XXI century. Also commercialization of Sc-containing aluminum alloys has been started in Russia in the 1980s and some of these examples are still unique despite growing globally interest to application of $\mathrm{Sc}$ in Al.

\section{Acknowledgment}

Although this paper is a review of research done mostly by others, I would like to express gratitude to people that have been actively involved in studying $\mathrm{Al}-\mathrm{Sc}$ alloys and whom I had an honor to meet and collaborate with: Dr L.S. Toropova, Dr Yu.A Filatov, Dr T.V.

Dobatkina, Dr M.L. Kharakterova, Dr A.N. Kamardinkin, Dr B.V. Ovsyannikov.

\section{References}

1. Willey LA (1971) Aluminum Scandium Alloy, USA Patent US3619181 A.

2. Naumkin OP, Terekhov VT, Savitskii EM (1965) Izv. Akad. Nauk SSSR, Met. (4): 176179.

3. Drits ME, Kadaner ES, Dobatkina TV, Turkina NI (1973) Izv. Akad. Nauk SSSR, Met. (4):213-217.

4. Murray J L (1998) J. Phase Equilibria 19(4): 380-384.

5. Cacciamani G, Riani P, Borzonea G, Parodi N, Saccone A, Ferro R, Pisch A, SchmidFetzer R (1999) Intermetallics 7: 101-108.

6. Wang F, Eskin DG, Khvan AV, Starodub KF, Lim JJH, Burke MG, Connolley T, Mi J (2017) Scr. Mater. 133: 75-78.

7. Drits ME, Toropova LS, Bykov YuG (1983) Izv. Akad. Nauk SSSR, Met. (1): 179-182.

8. Toropova LS, Kamardinkin AN (1989) Tzvetn. Met. (5): 104-106.

9. Rechkin VN, Lamikhov LK, Samsonova TI (1964) Kristallografiya 9(3): 405-408.

10. Drits ME, Toropova LS, Gushchina FL, Fedotov SG (1984) Izv. Vyssh. Uchebn. Zaved., Tsvetn. Met. (1): 123-124. 
11. Toropova LS, Eskin DG, Kharakterova ML, Dobatkina TV (1998) Advanced Aluminum Alloys Containing Scandium, Gordon \& Breach OPA, Amsterdam.

12. Toropova LS, Kamardinkin AN, Kinzhibalo VV, Tyvanchuk AT (1990) Fiz. Met.

Metalloved. 69-70(12) 108-111.

13. Kamardinkin AN, Dobatkina TV, Rostova TD (1991) Izv. Akad. Nauk SSSR, Met. (2): 214-216.

14. Toropova LS, Dobatkina TV, Kamardinkin AN (1992) Izv. Akad. Nauk SSSR, Met. (5): $140-143$.

15. Turkina NI, Kuz'mina VI (1976) Izv. Akad. Nauk., Met. (4) 208-212.

16. Drits ME, Pavlenko SG, Toropova LS, Bykov YuG, Ber LB (1981) Dokl. Akad. Nauk SSSR 257 (2): 353-356.

17. Belov NA, Eskin DG, Aksenov AA (2005) Multicomponent Phase Diagrams.

Applications for Commercial Aluminum Alloys, Elsevier, Amsterdam.

18. Drits ME, Toropova LS, Bykov YuG, Ber LB, Pavlenko SG (1982) Isv. Akad. Nauk SSSR, Met. (1) 173-178.

19. Drits ME, Ber LB, Bykov YuG, Toropova LS, Anastas'eva GK (1984) Fiz. Met.

Metalloved. 57(6) 1172-1179.

20. Toropova LS, Bykov, YuG, Lazorenko VM, Platov YuM (1982) Fiz. Met. Metalloved. 54 (1): 201-203.

21. Belov NA, Alabin AN, Eskin DG, Istomin-Kastrovskii VV (2006) J. Mater. Sci. 41: $5890-5899$.

22. Kharakterova ML, Eskin DG, Toropova LS (1994) Acta Metall. 42 (7) 2285-2290.

23. Miura Y, Horikawa K, Yamada K, Nakayama M (1994) In: Sanders, TH, Starke EA (eds) The $4^{\text {th }}$ Int. Conf. on Aluminum Alloys: Their Physical and Mechanical Properties. Vol. 2, Atlanta: Georgia Institute of Technology, p 161-168.

24. Drits ME, Toropova LS, Bykov YuG (1985) Izv. Vyssh. Uchebn. Zaved., Tsvetn. Metall. (4): 80-84.

25. Royset J, Ryum N (1994) In: Sanders, TH, Starke EA (eds) The $4^{\text {th }}$ Int. Conf. on Aluminum Alloys: Their Physical and Mechanical Properties. Vol. 1, Atlanta: Georgia Institute of Technology, p 194-201.

26. Yelagin VI, Zakharov VV, Rostova TD, Filatov YuA (1986) In: Metallovedenie, lit'e i obrabotka legkikh splavov. Moscow: Metallurgiya, p 180-189.

27. Kharakterova ML, Eskin DG, Rokhlin LL (1997) Metally (1): 123-128.

28. Lamikhov LK, Samsonov GV (1964) Tsvetn Met. (8): 79-82. 
29. Turkina NI, Semenova EV (1992) Tekhnol. Legk. Spl. (1): 57-59.

30. Yelagin VI, Zakharov VV, Rostova TD, Filatov YuA (1986) In: Metallovedenie, lit'e i obrabotka splavov. Moscow: VILS, p 6-16.

31. Yelagin VI, Zakharov VV, Filatov YuA, Rostova TD (2006) In: Perspektivnye tekhnologii legkikh i spetsial'nykh splavov. Moscow: Fizmatlit, p 181-193

32. Grushko O, Ovsyannikov B, Ovchinnikov V (2017) Aluminum-Lithium Alloys. Process Metallurgy, Physical Metallirgy and Welding, Boca Raton: CRC Press.

33. Ovsyannikov BV, Popov VI (2010) In: Proceedings of the 12th International Conference on Aluminium Alloys. Tokyo: Jpn. Inst. Light Metals, p 441-446 